\title{
Balancing tensions: Buffering the impact of organisational restructuring and downsizing on employee well-being
}

\author{
Author(s): Brian Harney (DCU Business School, Dublin City University, Ireland); Na Fu \\ (Trinity Business School, Trinity College Dublin, the University of Dublin, Ireland); Yseult \\ Freeney (DCU Business School, Dublin City University, Ireland) \\ Citation: Harney, B., Fu, N., \& Freeney, Y. (2018). Balancing tensions: Buffering the impact of \\ organisational restructuring and downsizing on employee well-being. Human Resource \\ Management Journal, 28(2), 235-254. https://onlinelibrary.wiley.com/doi/10.1111/1748- \\ $\underline{8583.12175}$
}

\begin{abstract}
This study examines the impact of employee experiences of restructuring and downsizing on well-being. The job demands-resources model was used to develop hypotheses related to job demands in the form of work intensity and job resources in the form of consultation. The job demands-resources model allows for direct incorporation of employee perceptions and does not assume a singular, predetermined consequence of HRM practices. Hypotheses were tested via structural equation modelling on a nationally representative sample of over 5,110 employees from the Republic of Ireland in 2009. The findings indicate that work intensity serves as a conduit through which experiences of restructuring and downsizing negatively impact employee well-being. Notably, consultation served as a buffer, diminishing the extent of this negative experience. The findings illuminate the complex pathways that shape how restructuring and downsizing are perceived by employees and the consequences for well-being. We discuss the theoretical and managerial implications of these findings.
\end{abstract}

Key words: consultation, downsizing, employee voice, job demands-resources, well-being

Please cite as: Harney, B., Fu, N., \& Freeney, Y. (2018). Balancing tensions: Buffering the impact of organisational restructuring and downsizing on employee well-being. Human Resource Management Journal, 28(2), 235-254. https://onlinelibrary.wiley.com/doi/10.1111/1748$\underline{8583.12175}$ 


\section{INTRODUCTION}

Restructuring and downsizing are increasingly common practices amongst organisations, serving as a highly visible manifestation of organisational change (Cascio, 1993; Trevor \& Nyberg, 2008). In the context of reorientations brought about by economic decline and financial crisis, restructuring and downsizing are critical levers to cut costs and sustain viability (Cameron, 1994; Halbesleben, Wheeler, \& Paustian-Underdahl, 2013; López-Bohle, Bal, Jansen, Leiva, \& Alonso, 2016). Despite this prominence, the organisational benefits of restructuring and downsizing remain contested and variable (Datta, Guthrie, Basuil, \& Pandey, 2010; de Jong et al., 2016). At the employee level, concepts such as "survivor sickness" and "psychological contract breach" depict the difficult realities confronted by remaining employees (Brockner et al., 2004; de Jong et al., 2016). A longstanding challenge for organisations concerns how they might ameliorate the extent of this negative experience. This becomes especially critical in economic contexts where there is a more limited palette of HR options available, and yet a greater reliance on surviving employees (Roche \& Teague, 2014).

This research applies the job demands-resources (JD-R) model to explore how employee experiences of restructuring and downsizing impact well-being in the context of the Irish economic recession. Although recent research has advanced our understanding of the impact of lay-offs and restructuring during recession, it has focused more on macro institutional factors (Goyer, Clark, \& Bhankaraully, 2016) or challenges for managers and HR professionals (Iverson \& Zatzick, 2011; Teague \& Roche, 2014). When employees are incorporated, this is often via narrow concepts such as psychological contract breach and managerial support (López-Bohle et al., 2016), without a holistic lens of inquiry to illuminate key relationships. Moreover, research tends to rely on secondary company data (Goyer et al., 2016; Norman, Butler, \& Ranft, 2013) or explore particular contexts (e.g., Kawai, 2015; López-Bohle et al., 2016; Parker, Chmiel, \& Wall, 1997). The current paper provides a broader, systematic understanding by drawing on a nationally representative survey examining employees' workplace experiences in the Republic of Ireland during 2009. This sample is particularly appropriate for the application of the JD-R model, providing a core focus on employees' lived experiences of restructuring and downsizing. Notably, research finds that managerial perceptions of workplace experiences tend to be positively skewed and frequently diverge from those reported by employees (Geare et al., 2014). By contrast, employee perceptions offer a more rounded means to evaluate HRM interventions (Bowen \& Ostroff, 2004), providing more proximate indicators of attitudes, behaviour, and wellbeing (e.g., Wood \& de Menezes, 2011). With specific reference to the HRM-well-being relationship, Boxall and colleagues argue that "we need a theory that speaks to the experience of work and employment from the employee perspective" (Boxall, Guthrie, \& Paauwe, 2016, p. 106). Incorporating such employee perceptions becomes especially significant in the context of restructuring and downsizing given that they are likely to result in direct changes to the

Please cite as: Harney, B., Fu, N., \& Freeney, Y. (2018). Balancing tensions: Buffering the impact of organisational restructuring and downsizing on employee well-being. Human Resource Management Journal, 28(2), 235-254. https://onlinelibrary.wiley.com/doi/10.1111/1748$\underline{8583.12175}$ 
conditions of employment and the nature of work for employees (Russell \& McGinnity, 2014). Indeed, without appreciating employee subjective experiences, the consequences of reorientation on well-being are likely to be underestimated (Rafferty \& Jimmieson, 2017). The paper contributes to existing understanding in a threefold manner.

First, the paper draws on the established JD-R model (Bakker \& Demerouti, 2007) to offer insights into how employee experiences of restructuring and downsizing have consequences for well-being and job satisfaction. The JD-R has particular utility in this task as it is founded on employee perceptions and does not assume a singular, predetermined outcome (Ehrnrooth \& Björkman, 2012; Van de Voorde, Van Veldhoven, \& Veld, 2016). Drawing on the logic of the JD-R enables us to explore the dynamics of restructuring and downsizing in a systematic way, to examine how their implementation is perceived by employees and explore subsequent consequences for individual and job related outcomes. This serves to complement organisational and managerial studies on the nature of organisational restructuring and downsizing in the context of economic recession (Goyer et al., 2016; Roche \& Teague, 2014). This approach also aligns with independent calls for a more process-based understanding made across the restructuring (de Jong et al., 2016), downsizing (Datta et al., 2010), and HRM literatures (Boxall \& Macky, 2009).

Second, the logic of JD-R allows us to explore key moderating factors that may serve to limit or buffer the negative experience of restructuring and downsizing. Although employees are likely to experience greater health impairing demands, including greater work intensity, as a result of restructuring and downsizing (Russell \& McGinnity, 2014), various resources can serve to mitigate the extent of these negative consequences. Indeed, Bakker, Hakanen, Demerouti, and Xanthopoulou (2007) and Hakanen, Bakker, and Demerouti (2005) indicate that the moderating impact of resources is particularly salient when job demands are high. We explore the role of consultation as one such prospective resource. In the context of change, consultation has been found to facilitate sense making, reduce employee uncertainty, and limit cynicism (Brown \& Cregan, 2008). Parker et al. (1997) found that employee participation was a key variable in reducing the negative impact of downsizing (via voluntary turnover and wastage) in a longitudinal case study of an organisation introducing an empowerment initiative. In the context of severe recessionary circumstances, consultation is an especially relevant resource to explore as it is something organisations retain direct control over, whereas alternative HR levers such as financial motivation and training are likely to be severely curtailed (Eurofound, 2014; Roche \& Teague, 2014). In support of our focus on consultation, de Jong et al. (2016) conclude their recent review of restructuring recommending that research better incorporates process dimensions including "the degree and quality of participation and communication" (p. 109). In an Irish context, there have been similar calls for research to examine how change can be best managed to have a less detrimental impact on employee well-being (Russell \& McGinnity, 2014, p. 18). We not only address such calls but also offer the theoretical logic of JD-R as a means to

Please cite as: Harney, B., Fu, N., \& Freeney, Y. (2018). Balancing tensions: Buffering the impact of organisational restructuring and downsizing on employee well-being. Human Resource Management Journal, 28(2), 235-254. https://onlinelibrary.wiley.com/doi/10.1111/1748$\underline{8583.12175}$ 
do so. This enables us to explore the interaction of demands and resources whereas previous research has considered "dual pathways" of mutual gains or critical HRM to the neglect of more integrated and nuanced understanding (Van de Voorde et al., 2016).

Our third contribution stems from the context under examination. In contrast to restructuring and downsizing in the service of continuous improvement or strategic empowerment (e.g., Parker et al., 1997), reorientation induced by exogenous shocks such as recession is said to result in substantial and accelerated organisational interventions with particularly severe employee consequences (Cameron, 1994; Kozlowski, Chao, Smith, \& Hedlund, 1993). Exemplar is the recent global financial crisis that induced significant organisational restructuring and downsizing (Iverson \& Zatzick, 2011; López-Bohle et al., 2016; Van Dierendonck \& Jacobs, 2012), resulting in 20 million job losses across the globe (Kawai, 2015). Eurofound (2014) reported a significant $25 \%$ differential in negative employment outcomes in those countries most impacted by the recession. Ireland represents a critical case in this regard, as it experienced the most dramatic decline of industrial nations between 2007 and 2012 (Kinsella, 2012). This period saw unemployment move from $4.6 \%$ to peak at $15.2 \%$ in 2012 , and data from national employee surveys indicate a statistically significant increase in restructuring between boom and bust periods (Russell \& McGinnity, 2014). This contextual backdrop offers a unique window to explore the type of "extreme contingencies" that authors have suggested will critically inform the dynamics of the HRM-well-being relationship (Guest, 2017; Peccei, van de Voorde, \& Van Veldhoven, 2012).

The paper is structured as follows. First, we present the broad context to examine the impact of experiences of restructuring and downsizing on employee well-being and job satisfaction. We then detail the JD-R model and leverage its logic for the formulation of hypotheses related to demands, in the form of work intensity, and resources, in the form of consultation, and their combined impact on employee outcomes of well-being and job satisfaction. The methodology is presented prior to an overview of the findings and a discussion of key implications for theory and practice.

\section{CONTEXT AND IMPACT OF DOWNSIZING AND RESTRUCTURING}

Although downsizing can be understood in a multifaceted manner, we follow Datta et al. (2010) in examining employee downsizing, as lay-offs represent the most virulent form of downsizing (Trevor \& Nyberg, 2008). Employee downsizing constitutes a "significant reduction of the workforce" (Mellahi \& Wilkinson, 2010, p. 2291) as part of a planned elimination of positions or jobs (Cascio, 1993) in an attempt to sustain or enhance performance (Budros, 1999; Norman et al., 2013). As per McKinley and Scherer (2000, p. 736), restructuring can be understood as "as any major reconfiguration of internal administrative structure that is associated with an

Please cite as: Harney, B., Fu, N., \& Freeney, Y. (2018). Balancing tensions: Buffering the impact of organisational restructuring and downsizing on employee well-being. Human Resource Management Journal, 28(2), 235-254. https://onlinelibrary.wiley.com/doi/10.1111/1748$\underline{8583.12175}$ 
intentional management change program." Although downsizing refers to employee headcount reduction and restructuring captures organisational reconfigurations, in practice, the terms are not mutually exclusive (Kawai, 2015). With respect to the "constellation" of pressures for workforce reductions and the nature of change required (Kalimo, Taris, \& Schaufeli, 2003), a critical distinction can be made between downsizing and restructuring as either planned, continuous improvement (e.g., Parker et al., 1997) versus reorientations of the type mandated by exogenous shocks and short-term need (Cameron, 1994). By drawing on data from the recessionary context of the Republic of Ireland, we focus on the latter understanding. Restructuring and downsizing as reorientations are said to result in more dramatic and negative experiences for employees, and are frequently characterised by "less concern for process" (Kozlowski et al., 1993, p. 306). Given the uncertainties that a recession brings to organisations and the general reduction in morale associated with cuts and austerity measures (Amabile \& Conti, 1999; Mellahi \& Wilkinson, 2010), lowered well-being is likely. In this study, we assess this by exploring employee well-being as operationalised by two commonly used indicatorsemotional exhaustion and job satisfaction (Bakker \& Oerlemans, 2011).

\section{EXPLORING EMPLOYEE EXPERIENCES: JOB-DEMANDS AND RESOURCES}

The JD-R model provides a systematic means to explore the dynamics of restructuring and downsizing. The basic tenet of the JD-R model is that although jobs vary considerably in terms of work characteristics, it is still possible to group these characteristics into two broad categories - namely, job demands and job resources. All occupations have a particular set of job demands (i.e., facets of a job that require physiological, cognitive, or emotional effort such as work pressure, demanding tasks, or emotional labour) and job resources (i.e., facets of a job that enable goal achievement, help to cope with demands, or contribute to development). According to the logic of the JD-R model, the balance between job resources and demands is vital to the experience of positive work outcomes and favourable well-being consequences (Bakker \& Demerouti, 2007). The JD-R model is proposed as a constructive model for advancing knowledge in the area of well-being, in that it captures both negative and positive dimensions (cf. Ehrnrooth \& Björkman, 2012) and provides for a clearer delineation of the role of specific HRM practices (Guest, 2017). Notably, the JD-R model proposes that the context of high job demands and low resources results in increased strain and impaired well-being. By contrast, high demands balanced with high resources can foster more positive outcomes. By affording direct attention to employee perceptions of implementation of restructuring and downsizing, the JD-R model moves research beyond simply examining direct employee experiences (cf. Russell \& McGinnity, 2014), towards exploring the interaction of practices that shape the nature of these experiences. This at once addresses calls for a more process-based understanding (de Jong et al.,

Please cite as: Harney, B., Fu, N., \& Freeney, Y. (2018). Balancing tensions: Buffering the impact of organisational restructuring and downsizing on employee well-being. Human Resource Management Journal, 28(2), 235-254. https://onlinelibrary.wiley.com/doi/10.1111/1748$\underline{8583.12175}$ 
2016; Katou, Budhwar, \& Patel, 2014) while providing a theoretical logic for understanding how restructuring and downsizing are perceived by employees and impact well-being (Boxall \& Macky, 2014).

\section{DEMANDS: THE MEDIATING ROLE OF WORK INTENSITY}

From an employee perspective, HR practices have been found either to signal recognition and commitment, leading to enhanced well-being (Kooij et al., 2013), or alternatively to increase workload and lower self-esteem, resulting in various negative physical and psychological states (Danna \& Griffin, 1999). Job demands traditionally lead to additional effort and the depletion of employee energy (Bakker, Demerouti, \& Sanz-Vergel, 2014). Drawing on data from the European Working Conditions Surveys, Avgoustaki (2016) found that uncertainty around work and changing conditions were positively related to extensive work effort. In the context of recession, downsizing and restructuring are likely to lead to enhanced responsibility and work pressure (Russell \& McGinnity, 2014), so-called work intensity. Work intensity comprises a time component and an intensity perspective and involves multiple demands (Burke, Singh, \& Fiksenbaum, 2010). Empirically, Green (2004) reported that the experience of job reductions in the previous 12 months had a significant influence on increased work intensification for employees. Hence, our first hypothesis is that employee experiences of restructuring and downsizing in a recessionary context result in demands, manifested as work intensity.

H1 Employee perceptions of restructuring (1a) and downsizing (1b) lead to enhanced demands for employees, manifest in work intensity.

Work intensity bears noteworthy implications for employee well-being and is predictive of psychological distress, as well as physical health problems (Wichert, 2002) and negative employee outcomes (e.g., Macky \& Boxall, 2008). In line with JD-R, significant demands in the form of work intensity, such as having to work under pressure and not having sufficient time to achieve core work goals are especially likely to lead to negative well-being outcomes, including exhaustion (Bakker et al., 2014). When employees perceive higher levels of work intensity, they are more likely to feel exhausted and less satisfied with their jobs; in short, it impairs their wellbeing (Kroon, van de Voorde, \& van Veldhoven, 2009). Thus, our second hypothesis is that work intensity is positively related to exhaustion and negatively related to job satisfaction.

$\mathrm{H} 2$ Work intensity is positively related to employee exhaustion (2a) and negatively related to job satisfaction (2b).

Calls to further investigate the often contradictory relationships between HR practices and wellbeing are increasingly prominent in the literature (Boxall et al., 2016; Peccei et al., 2012). In particular, authors have argued that the processes by which restructuring and downsizing impact

Please cite as: Harney, B., Fu, N., \& Freeney, Y. (2018). Balancing tensions: Buffering the impact of organisational restructuring and downsizing on employee well-being. Human Resource Management Journal, 28(2), 235-254. https://onlinelibrary.wiley.com/doi/10.1111/1748$\underline{8583.12175}$ 
well-being require further elucidation (Kalimo et al., 2003; Russell \& McGinnity, 2014). We deploy the JD-R to argue that employee experiences of restructuring and downsizing impact on well-being because they yield demands for employees in the form of work intensity, placing employees under more pressure because of increased workload and fears of job insecurity (Russell \& McGinnity, 2014). Such practices can signal to employees that they are not valued, violating the need for recognition, which is a fundamental requirement for employee well-being (Malasch \& Leiter, 1997). The loss of colleagues due to downsizing can have a detrimental impact on the sense of community, with employees sensing a loss of support and cohesion, resources that act as important determinants of well-being (Malasch \& Leiter, 1997; Warr, 1987). With respect to consequences, research examining employee experiences has typically found unintended, negative consequences of restructuring and downsizing (Brockner et al., 2004). Of the 23 studies reviewed by de Jong et al. (2016), 18 (78\%) reported a negative impact of restructuring on well-being, whereas downsizing has likewise been found to reduce job satisfaction and impair well-being amongst survivors (Luthans \& Sommer, 1999). Data from the context of recession in Ireland suggest that such negative employee experience may be accentuated during periods of economic decline (Russell \& McGinnity, 2014). Indeed, it is claimed that exogenous shocks may function as a "jarring" event for employees, leading to purposeful reflection about their experience of work and circumstances (Rafferty \& Jimmieson, 2017; Trevor \& Nyberg, 2008). Consequently, we argue that it is demands, in the form of work intensity, that act as the conduit through which employee experiences of restructuring and downsizing negatively impact on well-being, and so, our third and fourth hypotheses are that

H3 Work intensity mediates the link between employee experiences of restructuring and exhaustion (3a) and job satisfaction (3b).

H4 Work intensity mediates the link between employee experiences of downsizing and exhaustion (4a) and job satisfaction (4b).

\section{BALANCING DEMANDS WITH RESOURCES: THE ROLE OF CONSULTATION}

Datta et al. (2010) called for greater understanding of the critical contingencies shaping the way restructuring and downsizing are actually introduced and implemented. According to the logic of JD-R, job resources can act as buffers against strain, exhibiting a particularly salient impact in the context of more intense demands (Bakker et al., 2007; Hakanen et al., 2005). Research has found such resources to include trust, employee justice, and general managerial support (Kalimo

et al., 2003; López-Bohle et al., 2016). Absent, however, has been a systematic framework that simultaneously allows for the incorporation and interaction between both resources and

Please cite as: Harney, B., Fu, N., \& Freeney, Y. (2018). Balancing tensions: Buffering the impact of organisational restructuring and downsizing on employee well-being. Human Resource Management Journal, 28(2), 235-254. https://onlinelibrary.wiley.com/doi/10.1111/1748$\underline{8583.12175}$ 
demands. This point is especially pertinent in the context of reorientation during recession, characterised by heightened demands and a significantly reduced palette of viable resource options (Roche \& Teague, 2014).

In this study, we propose consultation as a key job resource that involves employees in decision making, noting that this may serve to buffer negative experiences of restructuring and downsizing on well-being. Anecdotal evidence suggests that those rare organisations that successfully navigate the complexities of restructuring and downsizing dedicate attention to surviving employees, including via consultation about where efficiencies may exist and how improvements can be made (Cameron, Freeman, \& Mishra, 1991). Evidently, employees are not passive recipients of HR practices, rather they interpret and internalise meaning, thus rendering perceptions of informational justice significant (Colquitt, Conlon, Wesson, Porter, \& Ng, 2001). We know from the organisational change literature that information sharing and involvement facilitate sense making, reduce employee uncertainty and, critically, reduce employee cynicism of change (Brown \& Cregan, 2008). With reference to downsizing, Parker et al. (1997) found a significant role for participation in ameliorating negative well-being outcomes, albeit in a context of a single organisation deploying voluntary turnover and natural wastage as part of a broader empowerment initiative.

Consultation is a particularly noteworthy resource to explore in the context of restructuring and downsizing during recession as it is cost neutral and is something over which organisations retain direct control. Moreover, in the context of reorientation, the outcomes of restructuring and downsizing are said to be more severely felt (Kozlowski et al., 1993), rendering the prospective role of consultation all the more significant (Freeman \& Cameron, 1993). Iverson and Zatzick's (2011) study of HR managers found that a self-reported concern for employee morale and welfare (including via enhanced managerial communication and explanation) mitigated the negative effects of layoffs on productivity. In exploring how such factors might be interpreted by employees, it is likely that consultation will directly inform employee's attribution for the cause of, and subsequent reaction to, work demands during reorientation (Moore, 2000; Nishii \& Wright, 2008). Exploring the context of Greece, Katou et al. (2014) suggest that open communication during economic crisis facilitates the achievement of organisational goals. Consultation can help mitigate extreme anxiety, avoid employee reliance on their own subjective perceptions or informal rumours when interpreting restructuring and downsizing during reorientation, ultimately reducing resistance to change amongst survivors (Nishii \& Wright, 2008). Recently, Guest (2017) specifically pointed to the prospective role of practices such as consultation in ameliorating threats to well-being stemming from severe change. In an Irish context, Russell and McGinnity (2014) discussed how change in the midst of recession might be better managed, suggesting that consultation might reduce the negative consequences for wellbeing. Interestingly, organisational level reports of HR practices deployed during the recession in Ireland point to a paradoxical mix of retrenchment strategies combined with softer elements,

Please cite as: Harney, B., Fu, N., \& Freeney, Y. (2018). Balancing tensions: Buffering the impact of organisational restructuring and downsizing on employee well-being. Human Resource Management Journal, 28(2), 235-254. https://onlinelibrary.wiley.com/doi/10.1111/1748$\underline{8583.12175}$ 
such as communication, to engender employee engagement (Roche \& Teague, 2014). This raises an interesting question as to the impact of such hybrid approaches on employee experiences of work (Conway, Fu, Monks, Alfes, \& Bailey, 2015), with the JD-R model serving as a theoretical means to further explore this. Therefore, we propose the following final hypothesis.

H5 Consultation moderates the link between work intensity and exhaustion (5a) and job satisfaction (5b) such that when consultation is more extensive the extent of the negative impact is reduced.

A summary of our proposed model exploring the impact of employee experiences of restructuring and downsizing on employee well-being and key hypothesis as grounded in the JD$\mathrm{R}$ model is presented in Figure 1.

\section{METHODOLOGY}

\subsection{Sample and procedures}

This study is based on a large database of employee responses $(n=5,110)$ drawn from a National Workplace Survey of Employees conducted in Ireland in 2009. This was a telephone survey targeting employees (age 15 years and over) in the public and private sectors (excluding agriculture). Given the focus of the research on well-being, the employee represents the most "authentic respondent" (Boxall et al., 2016, p. 109), serving as the unit of analysis as opposed to the workplace or employer (cf. Russell \& McGinnity, 2014). Moreover, relying on multiple experiences purposefully enhances variance in predictor variables, in contra to traditional organisation or sector specific studies (Spreitzer \& Mishra, 2002). Following a pilot, the survey was administered by a third party agency utilising questionnaire scripted software (NIPO). NIPO provided capabilities in the following areas: managing Computer Assisted Telephone Interviewing; data entry; managing telephone sample numbers; managing appointments with respondents; and monitoring sample quotas and overall targets in order to track progress. It afforded a real-time monitoring system to ensure quality of interviewing was maintained. The sample was generated on a stratified random basis with quota control. Allowing for ineligibility and invalid telephone numbers, the survey yielded a $50 \%$ response rate. Each survey interview lasted an average time of 35 min (for technical details, see O'Connell, Russell, Watson, \& Byrne, 2010). Prior to analysis, the sample was reweighted using information from the Quarterly National Household Survey from the first quarter of 2009 to ensure that it was the representative of the full population of all employees in the Republic of Ireland. This was an opportune time for this survey as Ireland was in the midst of a dramatic reversal of economic fortunes as a result of the threefold confluence of a global downturn, a banking crisis and a property market crash (Kinsella, 2012). Such was the severity of conditions that in 2010 Ireland was forced to negotiate a "bail out" package from the "Troika" of the European Union, the European Central Bank, and

Please cite as: Harney, B., Fu, N., \& Freeney, Y. (2018). Balancing tensions: Buffering the impact of organisational restructuring and downsizing on employee well-being. Human Resource Management Journal, 28(2), 235-254. https://onlinelibrary.wiley.com/doi/10.1111/1748$\underline{8583.12175}$ 
the International Monetary Fund. As has been noted by other commentators (Roche \& Teague, 2012; Russell \& McGinnity, 2014), this unfortunate reality renders Ireland something of a "critical" or "exemplary" case.

FIGURE 1 Theoretical model: Exploring the impact of employee experiences of restructuring and downsizing on employee well-being

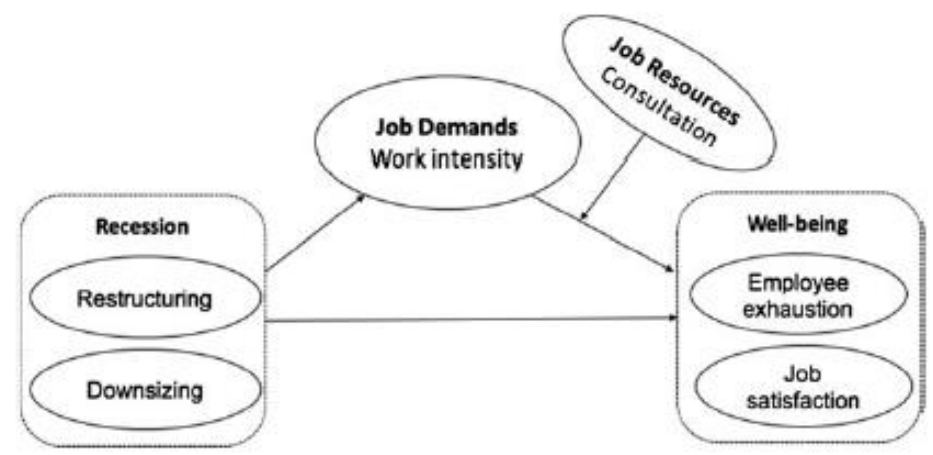

FIGURE 1 Theoretical model: Exploring the impact of employee experiences of restructuring and downsizing on employee well-being

Of the sample, $52 \%$ were female, $58 \%$ were from the private sector; $33 \%$ were from organisations with less than 20 employees; $31 \%$ were from organisations with more than 20 and less than 100 employees, leaving 36\% working in organisations of more than 100 employees. The average age was 40.59 years old $(\mathrm{SD}=11.84)$, the average working tenure was 11.44 years $(\mathrm{SD}=9.99)$, and with respect to education, $38 \%$ had university degrees.

\subsection{Measures}

\subsubsection{Organisational restructuring and downsizing}

Restructuring was measured by one binary variable. Respondents were asked if restructuring of the company/workplace had taken place over the last 2 years. It is coded as 1 indicating yes and 0 indicating no. With respect to downsizing, similar to Iverson and Zatzick (2011), respondents were asked if a reduction in overall staff numbers had taken place at their workplace over the last 2 years. This was coded as 1 indicating yes and 0 indicating no. This measurement approach echoes that deployed by Russell and McGinnity (2014), and conceptually, it finds support from Budros (1999, p. 70), who argued that "downsizing and restructuring are independent conceptually, but these phenomena may be linked empirically (causally)."

Please cite as: Harney, B., Fu, N., \& Freeney, Y. (2018). Balancing tensions: Buffering the impact of organisational restructuring and downsizing on employee well-being. Human Resource Management Journal, 28(2), 235-254. https://onlinelibrary.wiley.com/doi/10.1111/1748$\underline{8583.12175}$ 


\subsubsection{Employee exhaustion}

Similar to the OLBI scale (Bakker, Demerouti, \& Euwema, 2005), five items referred to general feelings of overworking, a desire for rest, and a state of physical exhaustion, with a particular emphasis on the spill over of said work characteristics to the personal/family dynamic (Gallie \& Russell, 2009). Sample items include "come home from work exhausted" and "feel too tired after work to enjoy the things you would like to do at home." A 5-point scale was used, ranging from 1 (never) to 5 (always).

\subsubsection{Work intensity}

This was measured with four items, closely reflecting the demanding aspects of Karasek's (1985) job content instrument, with a focus on the nature, speed, and occurrence of demanding work. Example items were "I work under a great deal of pressure" and "I never seem to have enough time to get everything done in my job." A 4-point Likert scale was used, ranging from 1 (strongly disagree) to 4 (strongly agree).

\subsubsection{Job satisfaction}

This was measured by four items adapted from Cook, Hepworth, Wall, and Warr (1983). A sample item is "In general, I am satisfied with my present job." A 4-point Likert scale was used, ranging from 1 (strongly disagree) to 4 (strongly agree).

\subsubsection{Consultation}

This was measured by four items. Participants were asked to indicate how they experience consultation in organisations covering the frequency, depth, nature, and evaluation of consultation. Sample items are "how often are you and your colleagues consulted before decisions are taken that affect you work" and "if changes in your work occur, how often are you given the reason why." A 5-point Likert scale was used, ranging from 1 (never) to 5 (always).

\subsubsection{Controls}

The first set of variables controlled for characteristics of individuals including gender, organisational tenure (years), education level, job grade, and health status. The second set of control variables included industry and firm characteristics that may affect employee outcomes. These included sector and firm size. Dummy variables are coded for the category variables, that is, gender, education, job grade, sector, and firm size. Individual organisational tenure was measured by the years working in the present workplace. Job security was controlled for in the model and was measured by one item; Please indicate the changes in your job security over the past 2 years: $1=$ decreased a lot, $4=$ increased a lot.

Please cite as: Harney, B., Fu, N., \& Freeney, Y. (2018). Balancing tensions: Buffering the impact of organisational restructuring and downsizing on employee well-being. Human Resource Management Journal, 28(2), 235-254. https://onlinelibrary.wiley.com/doi/10.1111/1748$\underline{8583.12175}$ 


\section{RESULTS}

The findings reveal a significant perception of change, with $48 \%$ of employees experiencing organisational restructuring and $57 \%$ experiencing downsizing. This reflects the contextual backdrop of the economic recession that was occurring in Ireland at the time. It also highlights the merits of further exploring the nature of employees' work experiences under such circumstances, in particular, with respect to well-being (Rafferty \& Jimmieson, 2017). Table 1 shows descriptive statistics, including the means, standard deviations, correlations, and reliabilities.

\subsection{Measurement models}

Confirmatory factor analysis (CFA) was conducted to confirm the distinctiveness of the continuous multiitem measurement constructs including work intensity, consultation, employee exhaustion, and job satisfaction. The CFA results provide good model fitness for a clear fourfactor structure $(\chi 2[105]=1,282.63, \mathrm{p}<.001$, comparative fit index $(\mathrm{CFI})=.95$, Tucker-Lewis index $(\mathrm{TLI})=.94$, root mean square error of approximation $(\mathrm{RMSEA})=.05$, and standardised root mean square residual $=.04)$. The proposed CFA model fitness is much better than the null model $(\chi 2[136]=25,768.71, \mathrm{p}<.001, \mathrm{CFI}=.00, \mathrm{TLI}=.00, \mathrm{RMSEA}=.20)$. The item loadings ranged from .50 to .77 on their respective factors, all of which were significant at .001 level. Because all of the data were collected from one source, and at the same time, common method bias may exist. Following recommendations by Podsakoff, MacKenzie, and Podsakoff (2012), common method variance was tested using the CFA common latent factor technique. An additional latent variable was added to the CFA analysis with constraining all paths to be equal and its variance to be 1 . By comparing the factor loadings of the CFA with only studied variables and with the CFA with additional common latent factor, differences were found for a very small number of items, suggesting that there is no serious common method variance that might affect the relationships amongst the variables.

\section{Table 1. Descriptive statistics (see end of doc)}

\subsection{Structural models}

To test the hypotheses, structural equation modelling (SEM) was conducted using IBM SPSS AMOS software. Mediation tests were conducted following Hayes' $(2009,2013)$ approach, by directly calculating the indirect effect. The moderation test was conducted via Moderated SEM (MSEM). MSEM is preferable to moderated regression analysis as it allows the investigation of two or more dependent variables (DVs) simultaneously, avoiding the loss of statistical power caused by the decreased reliability (Aiken \& West, 1991) and also the biased coefficient estimates (Ping, 1995). We adopted Ping's (1995) two-step approach to MSEM. Ping's approach uses one indicator of the latent product by the product of the sums of the relevant indicators, which reduces the complexity of calculating the interaction term. More importantly, Ping's

Please cite as: Harney, B., Fu, N., \& Freeney, Y. (2018). Balancing tensions: Buffering the impact of organisational restructuring and downsizing on employee well-being. Human Resource Management Journal, 28(2), 235-254. https://onlinelibrary.wiley.com/doi/10.1111/1748$\underline{8583.12175}$ 
approach rigorously calculates the loading and error for the indicator of the latent product based on the estimates from the measurement model, which is justified when the latent variables are unidimensional (Anderson \& Gerbing, 1988). In Step 1, after standardising all indicators for the independent variable (IV) and moderator, we calculated the latent interaction term that is based on the multiplication between the sum of standardised indicators for the IV and the sum of standardised indicators for the moderator. In Step 2, we used the equations indicated in the Appendix - which provides details on the MSEM analysis procedures - to calculate the path and variance estimates for the latent interaction term. Figure 2 and Table 2 present the results from the MSEM test, which simultaneously tested the mediation and moderation models $(\chi 2[420]=$ $3,229.64, \mathrm{p}<.001, \mathrm{CFI}=.93, \mathrm{TLI}=.91, \mathrm{RMSEA}=.04$, and standardised root mean square residual $=.04)$. This structured model provides a much better fit than the null model $(\chi 2[561]=$ $39,698.71, \mathrm{p}<.001, \mathrm{CFI}=.82, \mathrm{TLI}=.00, \mathrm{RMSEA}=.12)$. In addition, the model fit index indicates a good model fit of the structural model.

H1 proposed that restructuring (1a) and downsizing (1b) would be positively related to work intensity. The results in Figure 2 provide support for, whereby both restructuring and downsizing were positively linked to work intensity $(\beta=.12, p<.001$ for restructuring; $\beta=.08, p<.01$ for downsizing). Thus, H1 was supported.

$\mathrm{H} 2$ proposed that work intensity would have a negative impact on employee well-being, that is, it would increase employee exhaustion (2a) and reduce job satisfaction (2b). The results in Figure 2 show that, after controlling for both individual and organisational factors, work intensity was positively linked to employee exhaustion $(\beta=.66, \mathrm{p}<.001)$ and negatively linked to job satisfaction $(\beta=-.10, \mathrm{p}<.001)$. The R2 values were .56 for employee exhaustion and .25 for job satisfaction. Thus, $\mathrm{H} 2$ was supported.

$\mathrm{H} 3$ proposed that work intensity would mediate the negative impact of restructuring on employee well-being, represented by employee exhaustion (3a) and job satisfaction (3b). We followed Gunzler, Chen, Wu, and Zhang (2013) mediation SEM approach and ran a model that retained

Please cite as: Harney, B., Fu, N., \& Freeney, Y. (2018). Balancing tensions: Buffering the impact of organisational restructuring and downsizing on employee well-being. Human Resource Management Journal, 28(2), 235-254. https://onlinelibrary.wiley.com/doi/10.1111/1748$\underline{8583.12175}$ 
Figure 2 Mediation and moderation structural equation modelling results

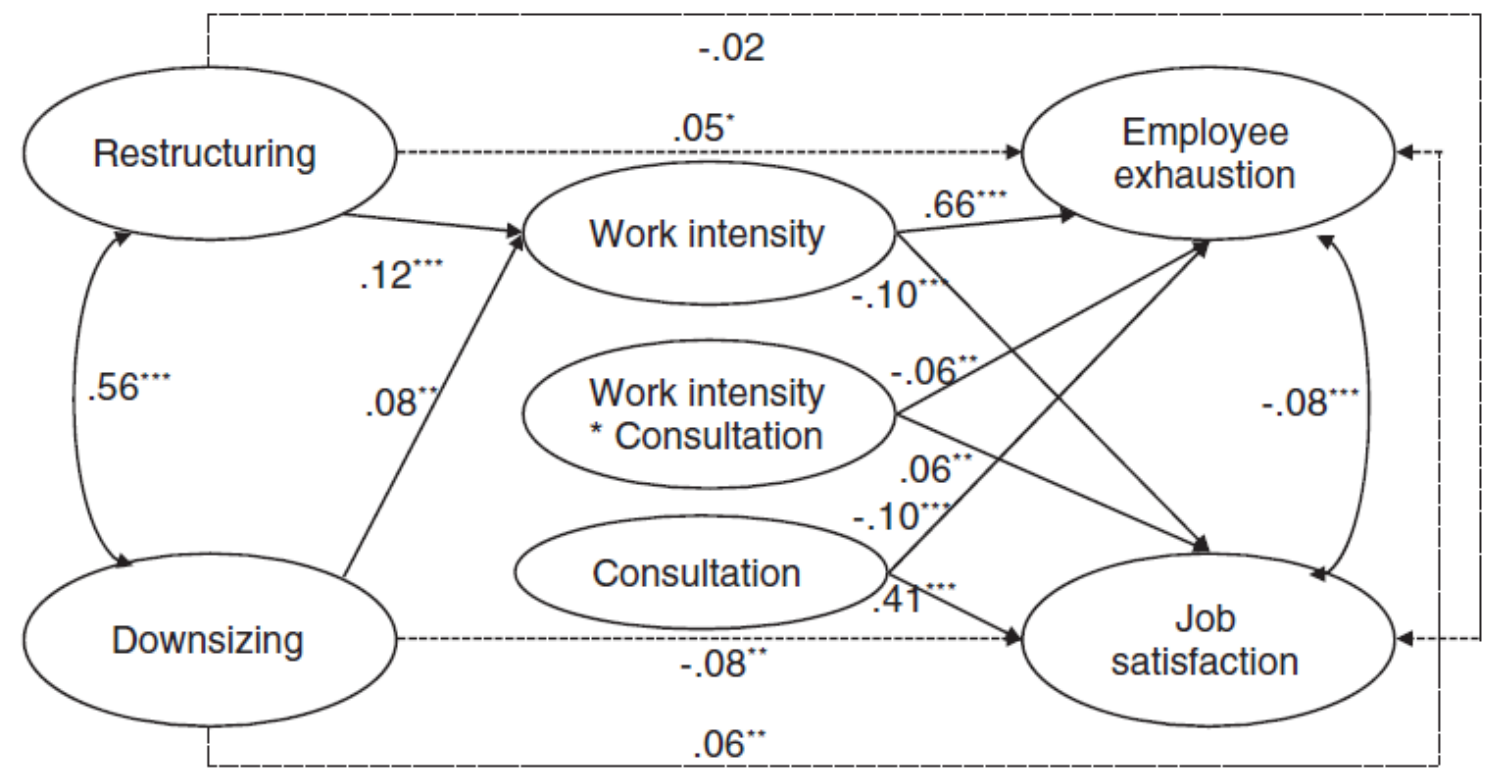

Note: Standardized coefficients were reported. $\mathrm{N}=4588$ (Listwise). All tests were two-tailed.

$\cdots p<.001, " p<.01, p<.05$

Direct Path

..... - Indirect Path

FIGURE 2 Mediation and moderation structural equation modelling results

links between the IVs and DVs. According to Gunzler et al. (2013), a mediation test via SEM requires significant links between the IV and the mediator (Me) as well as between the Me and the DV. We adopted Hayes' $(2009,2013)$ approach, which calculates the indirect effect between the IV and the DV, via the Me. We then used a bootstrapping test based on a random sample of 5,000 to calculate the confidence intervals for the indirect effect to check its robustness. For employee exhaustion, the effect of the IV (restructuring) on the Me (work intensity) was significant $(\beta=.12, \mathrm{p}<.001)$ and the effects of the Me (work intensity) on the DVs (employee exhaustion and job satisfaction) were significant too $(\beta=.66, \mathrm{p}<.001$ for employee exhaustion; $\beta=-.10, p<.001$ for job satisfaction), providing support for the mediated effect of work intensity on the relationship between restructuring and employee well-being. The impact of restructuring and employee exhaustion was significant $(\beta=.05, \mathrm{p}<.05)$, suggesting a partial mediation of restructuring on employee exhaustion via work intensity. The impact of restructuring and employee job satisfaction was not significant $(\beta=-.02$, ns), suggesting a full mediation of restructuring on employee job satisfaction via work intensity. For employee exhaustion, the indirect effect was .0629 and its $95 \%$ confidence intervals were $[.0384, .0912]$.

Please cite as: Harney, B., Fu, N., \& Freeney, Y. (2018). Balancing tensions: Buffering the impact of organisational restructuring and downsizing on employee well-being. Human Resource Management Journal, 28(2), 235-254. https://onlinelibrary.wiley.com/doi/10.1111/1748$\underline{8583.12175}$ 
For job satisfaction, the indirect effect was -.0070 and its $95 \%$ confidence intervals were $[-.0115,-.0039]$. Overall, the results support the mediated relationship of restructuring-work intensity-employee well-being. The small effect sizes in the confidence intervals for the indirect effect could be due to the dichotomous nature of the IVs, where the effect of IVs on DVs via Mes are smaller compared to the mediation models with similar scales. However, neither of the intervals include 0 , supporting the mediational role of work intensity in the relationships between restructuring and employee exhaustion and job satisfaction. Therefore, H3 was supported.

H4 proposed that work intensity would mediate the negative impact of downsizing on employee well-being, represented by employee exhaustion (4a) and job satisfaction (4b). Similar to the approach used to test H3 (Gunzler et al., 2013), we first checked the relationship between the IV (downsizing) and the Me (work intensity) and found it was significant $(\beta=.08, \mathrm{p}<.01)$. Based on the significant relationships found above between the Me (work intensity) and the DVs (employee exhaustion and work intensity) in the test of $\mathrm{H} 3$, support was found for the mediation model of downsizing to employee well-being via work intensity. The links between downsizing and employee well-being were significant $(\beta=.06, \mathrm{p}<.01$ for employee exhaustion; $\beta=-.08, \mathrm{p}$ $<.01$ for job satisfaction), suggesting a partial mediation between downsizing and employee well-being via work intensity. Based on Hayes' $(2009,2013)$ approach, we calculated the indirect effect as .0557 for employee exhaustion and -.0058 for job satisfaction. The bootstrapping confidence intervals using 5,000 bootstrapping samples at $95 \%$ are $[.0285, .0819]$ for employee exhaustion; and [-.0099, -.0028] for job satisfaction. Overall, the results provide further support for the mediation effect of work intensity on the relationship between downsizing and employee well-being. Similar to the above analysis, the confidence intervals do not cover 0 , though the effect sizes are small. The mediation model of downsizing with employee exhaustion and job satisfaction via work intensity is supported. Therefore, H4 was supported.

\section{TABLE 2 Effects of other variables on employee outcomes}

H5 proposed that consultation would moderate the link between work intensity and employee well-being, such that the relationship is stronger when having lower consultation. We adopted Ping's (1995) approach to MSEM using the three steps described by Cortina et al. (2001) (a) standardising all observed variables for the latent predictor and moderator; (b) creating an interaction term by multiplying the sum of observed variables of the predictor with the sum of observed variables of the moderator; and (c) fixing the measurement properties for the latent interaction term by using the factor loadings and measurement errors of the latent predictor and moderator variables. Results in Figure 2 show that the interaction term was positively linked to employee exhaustion $(\beta=-.06, \mathrm{p}<.01)$ and negatively linked to job satisfaction $(\beta=.06, \mathrm{p}<$ $.01)$. According to Dawson (2014),

Please cite as: Harney, B., Fu, N., \& Freeney, Y. (2018). Balancing tensions: Buffering the impact of organisational restructuring and downsizing on employee well-being. Human Resource Management Journal, 28(2), 235-254. https://onlinelibrary.wiley.com/doi/10.1111/1748$\underline{8583.12175}$ 
This interaction term is at the heart of testing moderation. If (and only if) this term is significant...we can say that $Z$ [consultation] is a statistically significant moderator of the linear relationship between $\mathrm{X}$ [work intensity] and $\mathrm{Y}$ [employee exhaustion and job satisfaction] (p. 2).

Similarly, Aguinis, Beaty, Boik, and Pierce (2005) define moderation as

[r]ejecting the null hypothesis [the coefficient for the interaction term is significant from 0] ... indicates that $\mathrm{Z}$ [consultation] moderates the relationship between $\mathrm{X}$ [work intensity] and $\mathrm{Y}$ [employee exhaustion and job satisfaction]. Stated differently, the slope of Y [employee exhaustion and job satisfaction] on $\mathrm{X}$ [work intensity] differs across values of $\mathrm{Z}$ [consultation] (p. 94).

In this study, the coefficients for the relationships between the interaction term (work intensity $\mathrm{X}$ consultation) and two DVs (employee exhaustion and job satisfaction) were both significant ( $\mathrm{p}<$ .01 ), which supports for the moderation effect. These results indicate the slopes of work intensity on employee well-being differ between high and low levels of consultation.

To illustrate the difference, Figures 3 and 4 plot the interactions between work intensity and consultation on employee exhaustion and job satisfaction. As shown in Figure 3, overall, exhaustion is higher when work intensity is higher. Compared to lower levels of consultation, the link between work intensity and employee exhaustion is stronger at higher levels of consultation. In addition, the level of employee exhaustion is higher when consultation is lower at both high and low levels of work intensity. This suggests that consultation is helpful in reducing employee exhaustion. Figure 4 shows that when consultation is higher, job satisfaction stays at similar levels when work intensity increases. When consultation is lower, job satisfaction decreases significantly when work intensity increases. The simple slopes tests provide further support. The relationship between work intensity and employee exhaustion was negative and differed from 0 at both low $(\mathrm{B}=.708, \mathrm{t}=45.823, \mathrm{p}<.001)$ and high $(\mathrm{B}=.552, \mathrm{t}=35.110, \mathrm{p}<.001)$ levels of consultation. The relationship between work intensity and job satisfaction was negative and differed from 0 at low $(\mathrm{B}=-.211, \mathrm{t}=-21.608, \mathrm{p}<.001)$ but not high $(\mathrm{B}=-.005, \mathrm{t}=-.483, \mathrm{~ns})$ levels of consultation. Together, these analyses demonstrate that links between work intensity and employee well-being are stronger when consultation is lower, supporting H5.

Please cite as: Harney, B., Fu, N., \& Freeney, Y. (2018). Balancing tensions: Buffering the impact of organisational restructuring and downsizing on employee well-being. Human Resource Management Journal, 28(2), 235-254. https://onlinelibrary.wiley.com/doi/10.1111/1748$\underline{8583.12175}$ 
FIGURE 3 Plot between work intensity and consultation on employee exhaustion

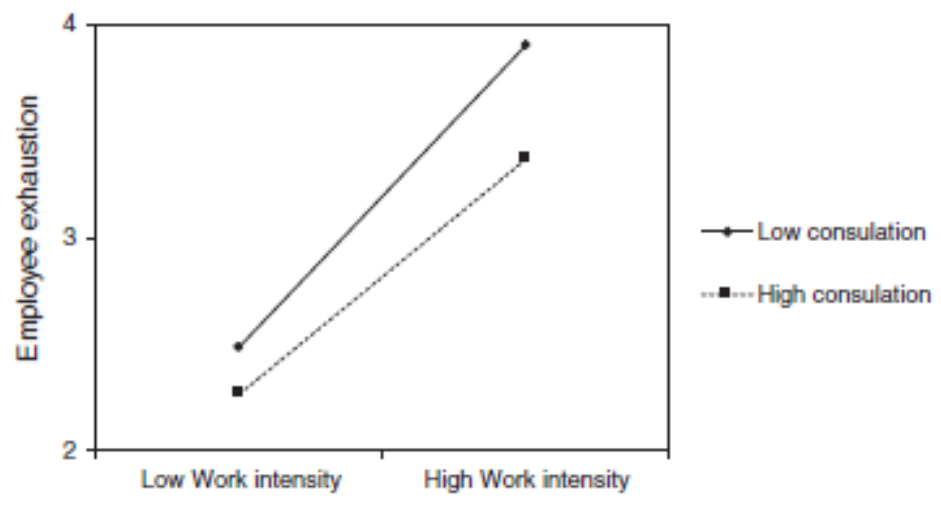

FIGURE 3 Plot between work intensity and consultation on employee exhaustion

\section{FIGURE 4 Plot between work intensity and consultation on job satisfaction}

FIGURE 3 Plot between work intensity and consultation on employee exhaustion

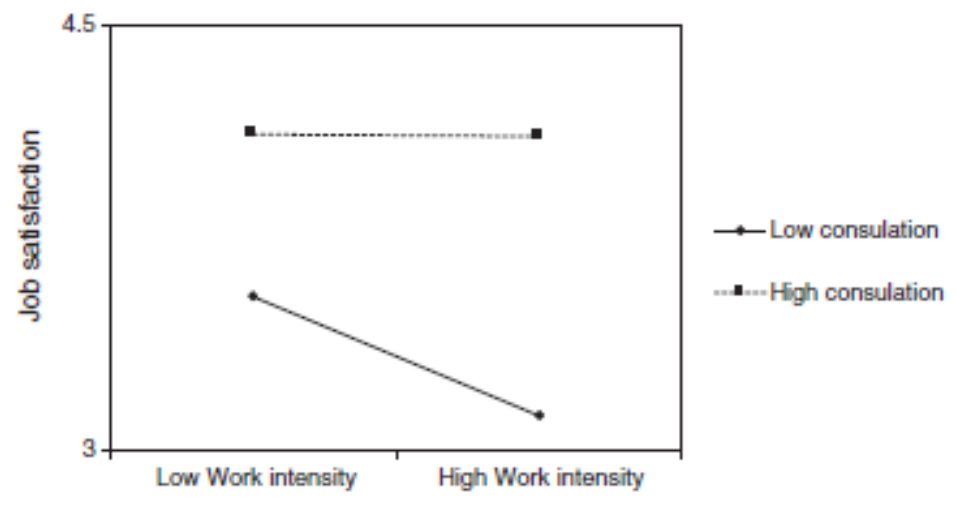

FIGURE 4 Plot between work intensity and consultation on job satisfaction

Please cite as: Harney, B., Fu, N., \& Freeney, Y. (2018). Balancing tensions: Buffering the impact of organisational restructuring and downsizing on employee well-being. Human Resource Management Journal, 28(2), 235-254. https://onlinelibrary.wiley.com/doi/10.1111/1748- 


\section{DISCUSSION}

Research on HRM and well-being has been consumed with exploring mutual gains outcomes during steady state conditions, representing a very unbalanced account of organisational realities. In contrast, this research examined the context of reorientation to surface the experiences of restructuring and downsizing and their effect on employee well-being. This at once appreciates the requirement for more in-depth exploration of how the approach taken to HRM is related to subsequent outcomes (Boxall et al., 2016) while also heeding calls to attend to extreme contingencies in the HRM well-being relationship (Peccei et al., 2012). Moreover, we extend understanding by drawing on a nationally representative survey of employees, bringing employee subjective experiences to the forefront of analysis. This is a necessary complement to organisational and managerial focused accounts of recession (Iverson \& Zatzick, 2011; Roche \& Teague, 2014) while moving research on reorientation beyond its traditional focus on single organisations or sectors (de Jong et al., 2016).

In realising our research objectives, we anchored our hypotheses in the theoretical logic of the JD-R model. The JD-R model has been increasingly recognised as a holistic lens of inquiry with potential to surface the dynamics of the HRM well-being relationship (Boxall et al., 2016; Peccei et al., 2012). To date, however, the JD-R model has rarely been applied to examine the impact of extreme contingencies such as reorientations, or in exploring the interaction of demands and resources in shaping employee outcomes of same. Our findings shed empirical light on both. Following the logic of the JD-R model, our findings evidence that employee experiences of restructuring and downsizing deplete well-being. Restructuring and downsizing detract from well-known drivers of well-being, diminishing the sense of security, feelings of being valued, and social support, amongst others (Malasch \& Leiter, 1997; Warr, 1987). Specifically, experiences of restructuring and downsizing were found to yield demands from employees in the form of work intensity. Work intensity in turn was associated with enhanced employee exhaustion and decreased job satisfaction. This not only demonstrates the negative impact of restructuring and downsizing (cf. Russell \& McGinnity, 2014) but also provides process-based understanding (Boxall et al., 2016; de Jong et al., 2016), whereby work intensity (as a form of job demand) serves as a key mediator shaping how restructuring and downsizing are experienced.

Moving beyond direct effects, this study was able to assess the role of job resources in balancing tensions and buffering any negative experiences of restructuring and downsizing. The value of a JD-R informed study is that it does not assume an exclusive positive stance, as per the mutual gains perspective (cf. Appelbaum, Bailey, Berg, \& Kalleberg, 2000), or a wholly pessimistic perspective as per the exploitation hypothesis (Kroon et al., 2009). The findings highlight that employee consultation served as a key job resource that diminished the negative experience of work intensity on employee well-being (Bakker et al., 2005). This not only highlights the role of

Please cite as: Harney, B., Fu, N., \& Freeney, Y. (2018). Balancing tensions: Buffering the impact of organisational restructuring and downsizing on employee well-being. Human Resource Management Journal, 28(2), 235-254. https://onlinelibrary.wiley.com/doi/10.1111/1748$\underline{8583.12175}$ 
moderators in shaping the way restructuring and downsizing are experienced (Datta et al., 2010), but also critically illustrates how the moderating role of resources assumes greater salience in the context of intensified demand (Bakker et al., 2007; Hakanen et al., 2005), as exemplified in the context of reorientation and related constraints (Cameron, 1994; Kozlowski et al., 1993).

Consultation is a particularly relevant resource in this instance as it has been shown to have a significant role in the broader organisational change literature by facilitating employee sense making, enhancing understanding and fostering greater buy-in (Kernan \& Hanges, 2002; Madlock, 2008). Consultation can be related to perceptions of autonomy and social support and is more direct and expansive than communication (Den Hartog, Boon, Verburg, \& Croon, 2013), as it implies a two-way interaction as a basis of social exchange (Blau, 1964). By purposefully examining the interaction between demands and resources, we illustrate how HR practices such as consultation can buffer the negative performance experiences of restructuring and downsizing for employee well-being. More extensive use of consultation HR practices can have a positive impact by providing resources known to be important for well-being, including a sense of control over one's work and clarity around role changes as a result of reorientation (Malasch \& Leiter, 1997; Warr, 1987). In exploring the frequency, depth, nature, and evaluation of consultation as a moderator in the link between work intensity and employee well-being, we find that when work is highly intensified, employees will feel less exhausted and less dissatisfied with their job the more extensive consultation that they experience (see Figure 3 and 4). This highlights that although more severe HR practices are inexorable at times, the negative effects for employees do not have to be likewise inevitable. Instead, opportune resources shape employees' experiences of such practices and can help them to experience less severe outcomes from stressful events (Britt, Adler, \& Bartone, 2001). Overall, this points to the "complex pattern of effects and trade-offs" between specific HRM practices and employee well-being (Van de Voorde et al., 2016), and consequently the merits of advancing conversations beyond exclusive considerations of mutual gains or exploitation (Boxall et al., 2016; Ehrnrooth \& Björkman, 2012).

\subsection{Practical application}

The findings indicate that the critical factor determining employee well-being outcomes in the context of restructuring and downsizing during recession is not simply what the organisation does but, critically, how it does it (Katou et al., 2014). Drawing attention to the role of process and implementation places HR management at centre stage in terms of ameliorating the most negative impact on those employees that remain with the organisation. Consultation is an especially relevant variable for firms confronted by recessionary circumstances as, unlike other HR practices (Chadwick, Hunter, \& Walston, 2004), there is little cost associated with its introduction and operation. Moreover, by engaging in consultation, the HR function can play a pivotal role in creating a greater sense of justice, in fostering trust and ultimately enhancing the productivity and commitment of surviving employees (Roche \& Teague, 2012; Trevor \&

Please cite as: Harney, B., Fu, N., \& Freeney, Y. (2018). Balancing tensions: Buffering the impact of organisational restructuring and downsizing on employee well-being. Human Resource Management Journal, 28(2), 235-254. https://onlinelibrary.wiley.com/doi/10.1111/1748$\underline{8583.12175}$ 
Nyberg, 2008). This hints at the benefits of using more systemic, inclusive, and behavioural HR (breadth) to mitigate against the negative implications of a purely technical and numerical approach to severe organisational change (depth) or so-called hybrid approaches (Conway et al., 2015; Roche \& Teague, 2014). Indeed, although a more inclusive approach has been exclusively associated with proactive restructuring and downsizing as continuous improvement (Kozlowski et al., 1993), the current findings highlight that good management and attention to process have equal merit in the context of reorientation (Cameron, 1994).

In the midst of uncertainty brought about by dramatic organisational change and recessionary contexts, managers would do well to dedicate time to listening and consulting with their employees. This is likely to both positively impact individual well-being and also organisational behavioural outcomes. Indeed, it is highly likely that remaining employees will have valuable insights about internal process improvements or the restructuring of jobs. Ultimately, in order to survive the adversities of a prevailing recessionary climate, most firms must make internal organisational and HR adjustments as a means of survival. Yet, in the absence of effective management, these may be necessary but not sufficient in order to realise expected benefits (Cameron et al., 1991).

\subsection{Limitation and future research}

Although this study is based on a large, nationally representative employee sample, it has limitations stemming from reliance on single source respondents and cross-sectional design. To circumvent some of these limitations, common method bias was comprehensively tested for, while exploration of moderation is likely to be more impervious to common method and respondent bias (Chang, Van Witteloostuijn, \& Eden, 2010). Nonetheless, the current research relies exclusively on employee perceptions of restructuring and downsizing as opposed to exploration of, or an assessment against, discrete and objectively assessed events. Future research should pursue multisource data collection, including drawing upon objective and subjective data. It would also be desirable for future research to collect relevant data at different time points allowing for better causal understanding of the consequential effect of restructuring and downsizing and its relationship to work intensity and employee well-being before and after recession or similar change. This would also allow for an assessment and distinction of whether consultation was mobilised in certain circumstances, or whether consultation was a culturally embedded practice and the result of this in differentiating firm and employee outcomes. More job characteristics could also be incorporated allowing for greater appreciation of the impact of context and choice (Datta et al., 2010; Marchington \& Kynighoul, 2012). As survey content was negotiated with multiple stakeholders, pragmatic decisions were made with respect to measures and scales. This likewise applies to similar studies using public databases (e.g., Wood, Van Veldhoven, Croon, \& De Menezes, 2012; Zatzick \& Iverson, 2006).

Please cite as: Harney, B., Fu, N., \& Freeney, Y. (2018). Balancing tensions: Buffering the impact of organisational restructuring and downsizing on employee well-being. Human Resource Management Journal, 28(2), 235-254. https://onlinelibrary.wiley.com/doi/10.1111/1748$\underline{8583.12175}$ 
Akin to Russell and McGinnity (2014), restructuring and downsizing were understood as accentuated in a recessionary context, with a particular focus on the critical case of the Republic of Ireland. However, although these organisational practices may be more likely during a recession, they are increasingly a norm in steady-state conditions as well. From the control variables, we also know that employees in different sectors experience differences in the outcome variables, such that public sector employees report greater work intensity than the semistate or the private sector. However, we did not find any significant differences related to perceptions of restructuring and downsizing across sectors. Of course, it must be acknowledged that our measures do not enable comparative insight into the scale of job losses or intensity of restructuring or allow further differentiation between the severities of the event. We would like to see future research adopt different measurements and research design methods to further test for mediation and moderation. Finally, employee involvement is likely to be more deeply embedded in coordinated market economies in contrast to the regulatory space and leeway available in liberal market economies (Marchington \& Kynighoul, 2012). This opens up the question of the role and impact of broader institutional structures in informing the nature and continuity of consultation mechanisms as part of organisational responses to economic crisis.

\section{CONCLUSION}

This paper has advanced understanding by deploying the JD-R model to explore employee experiences of restructuring and downsizing and their consequences for well-being. The JD-R model offers a sound theoretical base to accommodate contradictory findings rather than simply examining, or assuming, positive or negative experiences (Bakker et al., 2005; Ehrnrooth \& Björkman, 2012). The findings illuminate the complex pathways that shape how restructuring and downsizing are perceived by employees and impact well-being. Critically, the findings suggest that managerial interventions in the form of consultation can serve to weaken the negative link between work intensity and employee well-being, thus rendering the impact of organisational restructuring and downsizing less severe. Consultation is an especially relevant variable for firms confronted by recessionary circumstances as it requires little substantial investment while also being closely allied with perceptions of justice, fostering trust, and engendering employee buy-in. Overall, even in extreme recessionary contexts, agency can be critical in determining the ultimate impact of restructuring and downsizing on employee wellbeing. This reinforces the importance of effectively managing severe change, highlighting the dangerous consequences for employee-well-being and organisational performance of failing to do so.

Please cite as: Harney, B., Fu, N., \& Freeney, Y. (2018). Balancing tensions: Buffering the impact of organisational restructuring and downsizing on employee well-being. Human Resource Management Journal, 28(2), 235-254. https://onlinelibrary.wiley.com/doi/10.1111/1748$\underline{8583.12175}$ 


\section{ACKNOWLEDGEMENTS}

We wish to acknowledge Associate Editor Dr Martin Edwards and the reviewers for their detailed and constructive comments. We also wish to thank James Guthrie, DCU colleagues Lisa Van de Werff and Edel Conway, and participants at the AOM HRIC Conference, Beijing. Data for this research were accessed via the Irish Social Science Data Archive.

\section{REFERENCES}

Aguinis, H., Beaty, J. C., Boik, R. J., \& Pierce, C. A. (2005). Effect size and power in assessing moderating effects of categorical variables using multiple regression: A 30-year review. Journal of Applied Psychology, 90, 94-107.

Aiken, L. S., \& West, S. G. (1991). Multiple regression: Testing and interpreting interactions. Thousand Oaks, CA: Sage.

Amabile, T. M., \& Conti, R. (1999). Changes in the work environment for creativity during downsizing. Academy of Management Journal, 42, 630-640.

Anderson, J. C., \& Gerbing, D. W. (1988). Structural equation modelling in practice: A review and recommended two-step approach. Psychological Bulletin, 103, 411-423.

Appelbaum, E., Bailey, T., Berg, P., \& Kalleberg, A. (2000). Manufacturing advantage: Why high-performance work systems pay off. Ithaca, NY: Cornell University Press.

Avgoustaki, A. (2016). Work uncertainty and extensive work effort: The mediating role of human resource practices. Industrial and Labor Relations Review, 69(3), 656-682.

Bakker, A. B., \& Demerouti, E. (2007). The job demands-resources model: State of the art. Journal of Managerial Psychology, 22(3), 309-328.

Bakker, A. B., \& Oerlemans, W. (2011). Subjective well-being in organizations. In K. S. Cameron \& G. M. Spreitzer (Eds.), The Oxford handbook of positive organizational scholarship (pp. 178-189). Oxford: Oxford University Press.

Bakker, A. B., Demerouti, E., \& Euwema, M. C. (2005). Job resources buffer the impact of job demands on burnout. Journal of Occupational Health Psychology, 10(2), 170-180.

Bakker, A. B., Hakanen, J. J., Demerouti, E., \& Xanthopoulou, D. (2007). Job resources boost work engagement particularly when job demands are high. Journal of Educational Psychology, $99,274-284$.

Please cite as: Harney, B., Fu, N., \& Freeney, Y. (2018). Balancing tensions: Buffering the impact of organisational restructuring and downsizing on employee well-being. Human Resource Management Journal, 28(2), 235-254. https://onlinelibrary.wiley.com/doi/10.1111/1748$\underline{8583.12175}$ 
Bakker, A., Demerouti, E., \& Sanz-Vergel, A. I. (2014). Burnout and work engagement: The JDR approach. Annual Review of Organizational Psychology and Organizational Behavior, 1, 389411.

Blau, P. (1964). Exchange and power in social life. New York: Wiley.

Bowen, D. E., \& Ostroff, C. (2004). Understanding HRM-firm performance linkages: The role of the "strength" of the HRM system. Academy of Management Review, 29(2), 203-221.

Boxall, P., \& Macky, K. (2009). Research and theory on high-performance work systems:

Progressing the high-involvement stream. Human Resource Management Journal, 19(1), 3-23.

Boxall, P., \& Macky, K. (2014). High-involvement work processes, work intensification and employee well-being. Work, Employment and Society, 28(6), 963-984.

Boxall, P., Guthrie, J. P., \& Paauwe, J. (2016). Editorial introduction: Progressing our understanding of the mediating variables linking HRM, employee well-being and organisational performance. Human Resource Management Journal, 26(2), 103-111.

Britt, T. W., Adler, A. B., \& Bartone, P. T. (2001). Deriving benefits from stressful events: The role of engagement in meaningful work and hardiness. Journal of Occupational Health Psychology, 6(1), 53-63.

Brockner, J., Spreitzer, G., Mishra, A., Hochwarter, W., Pepper, L., \& Weinberg, J. (2004). Perceived control as an antidote to the negative effects of layoffs on survivors' organizational commitment and job performance. Administrative Science Quarterly, 49(1), 76-100.

Brown, M., \& Cregan, C. (2008). Organizational change cynicism: The role of employee involvement. Human Resource Management, 27(4), 667-686.

Budros, A. (1999). A conceptual framework for analysing why organizations downsize. Organization Science, 10(1), 69-82.

Burke, R. J., Singh, P., \& Fiksenbaum, L. (2010). Work intensity: Potential antecedents and consequences. Personnel Review, 39(3), 347-360.

Cameron, K. (1994). Strategies for successful organisational downsizing. Human Resource Management, 33(2), 189-211.

Cameron, K. S., Freeman, S. J., \& Mishra, A. K. (1991). Best practices in white-collar downsizing: Managing contradictions. The Executive, 5(3), 57-73.

Cascio, W. F. (1993). Downsizing: What do we know? What have we learned? The Academy of Management Executive, 7(1), 95-104.

Please cite as: Harney, B., Fu, N., \& Freeney, Y. (2018). Balancing tensions: Buffering the impact of organisational restructuring and downsizing on employee well-being. Human Resource Management Journal, 28(2), 235-254. https://onlinelibrary.wiley.com/doi/10.1111/1748$\underline{8583.12175}$ 
Chadwick, C., Hunter, L. W., \& Walston, S. L. (2004). Effects of downsizing practices on the performance of hospitals. Strategic Management Journal, 25(5), 405-427.

Chang, S. J., Van Witteloostuijn, A., \& Eden, L. (2010). From the editors: Common method variance in international business research. Journal of International Business Studies, 41(2), $178-184$.

Colquitt, J. A., Conlon, D. E., Wesson, M. J., Porter, C. O., \& Ng, K. Y. (2001). Justice at the millennium: A meta-analytic review of 25 years of organizational justice research. Journal of Applied Psychology, 86(3), 425-445.

Conway, E., Fu, N., Monks, K., Alfes, K., \& Bailey, C. (2015). Demands or resources? The relationship between HR practices, employee engagement, and emotional exhaustion within a hybrid model of employment relations. Human Resource Management, 55

Cortina, J. M., Chen, G., \& Dunlap, W. P. (2001). Testing interaction effects in LISREL: Examination and illustration of available procedures. Organizational Research Methods, 4(4), 324-360.

Danna, K., \& Griffin, R. W. (1999). Health and well-being in the workplace: A review and synthesis of the literature. Journal of Management, 25(3), 357-384.

Datta, D. K., Guthrie, J. P., Basuil, D., \& Pandey, A. (2010). Causes and effects of employee downsizing: A review and synthesis. Journal of Management, 36(1), 281-348.

Dawson, J. (2014). Moderation in management research: What, why, when, and how. Journal of Business and Psychology, 29(1), 1-19.

de Jong, T., Wiezer, N., de Weerd, M., Nielsen, K., Mattila-Holappa, P., \& Mockałło, Z. (2016). The impact of restructuring on employee well-being: A systematic review of longitudinal studies. Work \& Stress, 30(1), 91-114.

Den Hartog, D., Boon, C., Verburg, R., \& Croon, M. (2013). HRM, communication, satisfaction, and perceived performance: A cross-level test. Journal of Management, 39(6), 1637-1665.

Ehrnrooth, M., \& Björkman, I. (2012). An integrative HRM process theorization: Beyond signalling effects and mutual gains. Journal of Management Studies, 49(6), 1109-1135.

Eurofound (2014). Impact of the crisis on industrial relations and working conditions in Europe. Dublin: European Foundation for the Improvement of Living and Working Conditions.

Freeman, S. J., \& Cameron, K. S. (1993). Organizational downsizing: A convergence and reorientation framework. Organization Science, 4(1), 10-29.

Please cite as: Harney, B., Fu, N., \& Freeney, Y. (2018). Balancing tensions: Buffering the impact of organisational restructuring and downsizing on employee well-being. Human Resource Management Journal, 28(2), 235-254. https://onlinelibrary.wiley.com/doi/10.1111/1748$\underline{8583.12175}$ 
Gallie, D., \& Russell, H. (2009). Work-family conflict and working conditions in Western Europe. Social Indicators Research, 93(3), 445-467.

Geare, A., Edgar, F., McAndrew, I., Harney, B., Cafferkey, K., \& Dundon, T. (2014). Exploring the ideological undercurrents of HRM: Workplace values and beliefs in Ireland and New Zealand. International Journal of Human Resource Management, 25(16), 2275-2294.

Goyer, M., Clark, I., \& Bhankaraully, S. (2016). Necessary and sufficient factors in employee downsizing? A qualitative comparative analysis of lay-offs in France and the UK, 2008-2013. Human Resource Management Journal, 26(3), 252-268.

Green, F. (2004). Work intensity, discretion, and the decline in well-being at work. Eastern Economic Journal, 30(4), 615-625.

Guest, D. (2017). Human resource management and employee well-being: Towards a new analytic framework. Human Resource Management Journal, 27(1), 22-38.

Gunzler, D., Chen, T., Wu, P., \& Zhang, H. (2013). Introduction to mediation analysis with structural equation modeling. Shanghai Archives of Psychiatry, 25(6), 390-394.

Hakanen, J., Bakker, A., \& Demerouti, E. (2005). How dentists cope with their job demands and stay engaged: The moderating role of job resources. European Journal of Oral Sciences, 112, 479-487.

Halbesleben, J. R., Wheeler, A. R., \& Paustian-Underdahl, S. C. (2013). The impact of furloughs on emotional exhaustion, self- rated performance, and recovery experiences. Journal of Applied Psychology, 98(3), 492-503.

Hayes, A. F. (2009). Beyond Baron and Kenny: Statistical mediation analysis in the new millennium. Communication Monographs, 76(4), 408-420.

Hayes, A. F. (2013). Introduction to mediation, moderation, and conditional process analysis: A regression-based approach. New York: Guilford Press.

Iverson, R., \& Zatzick, C. (2011). The effects of downsizing on labor productivity: The value of showing consideration for employees' morale and welfare in high-performance work systems. Human Resource Management Journal, 50(1), 29-44.

Kalimo, R., Taris, T. W., \& Schaufeli, W. B. (2003). The effects of past and anticipated future downsizing on survivor well-being: An equity perspective. Journal of Occupational Health Psychology, 8, 91-109.

Karasek, R. A. (1985). Job content questionnaire and user's guide. Lowell, MA: University of Massachusetts.

Please cite as: Harney, B., Fu, N., \& Freeney, Y. (2018). Balancing tensions: Buffering the impact of organisational restructuring and downsizing on employee well-being. Human Resource Management Journal, 28(2), 235-254. https://onlinelibrary.wiley.com/doi/10.1111/1748$\underline{8583.12175}$ 
Katou, A., Budhwar, P., \& Patel, C. (2014). Content vs. process in the HRM-performance relationship: An empirical examination. Human Resource Management, 53(4), 527-544.

Kawai, N. (2015). Does downsizing really matter? Evidence from Japanese multinationals in the European manufacturing industry. International Journal of Human Resource Management, 26(4), 501-519.

Kernan, M. C., \& Hanges, P. J. (2002). Survivor reactions to reorganization: Antecedents and consequences of procedural, interpersonal, and informational justice. Journal of Applied Psychology, 87(5), 916-928.

Kinsella, S. (2012). Is Ireland really the role model for austerity? Cambridge Journal of Economics, 36(1), 223-235. 252

Kooij, D. T., Guest, D. E., Clinton, M., Knight, T., Jansen, P. G., \& Dikkers, J. S. (2013). How the impact of HR practices on employee well-being and performance changes with age. Human Resource Management Journal, 23(1), 18-35.

Kozlowski, S. W. J., Chao, G. T., Smith, E. M., \& Hedlund, J. (1993). Organizational downsizing: Strategies, interventions, and research implications. In C. L. Cooper, \& I. T. Robertson (Eds.), International review of industrial and organizational psychology (pp. 264332). London: Wiley.

Kroon, B., van de Voorde, K., \& van Veldhoven, M. (2009). Cross-level effects of highperformance work practices on burnout: Two counteracting mediating mechanisms compared. Personnel Review, 38(5), 509-525.

López-Bohle, S., Bal, P. M., Jansen, P. G., Leiva, P. I., \& Alonso, A. M. (2016). How mass layoffs are related to lower job performance and OCB among surviving employees in Chile: An investigation of the essential role of psychological contract. International Journal of Human Resource Management. https://doi.org/10.1080/09585192.2016.1138988

Luthans, B. C., \& Sommer, M. (1999). The impact of downsizing on workplace attitudes. Group \& Oragnization Management, 24, 46-70.

Macky, K., \& Boxall, P. (2008). High-involvement work processes, work intensification and employee well-being: A study of New Zealand worker experiences. Asia Pacific Journal of Human Resources, 46(1), 38-55.

Madlock, P. E. (2008). The link between leadership style, communicator competence, and employee satisfaction. Journal of Business Communication, 45(1), 61-78.

Malasch, C., \& Leiter, M. P. (1997). The truth about burnout: How organizations cause personal stress and what to do about it. San Francisco, CA: Jossey-Bass.

Please cite as: Harney, B., Fu, N., \& Freeney, Y. (2018). Balancing tensions: Buffering the impact of organisational restructuring and downsizing on employee well-being. Human Resource Management Journal, 28(2), 235-254. https://onlinelibrary.wiley.com/doi/10.1111/1748$\underline{8583.12175}$ 
Marchington, M., \& Kynighoul, A. (2012). The dynamics of employee involvement and participation during turbulent times. International Journal of Human Resource Management, 23(16), 3336-3354.

McKinley, W., \& Scherer, A. G. (2000). Some unanticipated consequences of organizational restructuring. Academy of Management Review, 25(4), 735-752.

Mellahi, K., \& Wilkinson, A. (2010). Slash and burn or nip and tuck? Downsizing, innovation and human resources. International Journal of Human Resource Management, 21(13), 22912305.

Moore, J. E. (2000). Why is this happening? A causal attribution approach to work exhaustion consequences. Academy of Management Review, 25, 335-349.

Nishii, L. H., \& Wright, P. (2008). Variability at multiple levels of analysis: Implications for strategic human resource management. In D. B. Smith (Ed.), The people make the place (pp. 225-248). New York: Psychology Press.

Norman, P. M., Butler, F. C., \& Ranft, A. L. (2013). Resources matter: Examining the effects of resources on the state of firms following downsizing. Journal of Management, 39(7), 20092038.

O'Connell, P. J., Russell, H., Watson, D., \& Byrne, D. (2010). The changing workplace: A survey of employees' views and experiences. Dublin: National Centre for Partnership and Performance.

Parker, S. K., Chmiel, N., \& Wall, T. D. (1997). Work characteristics and employee well-being within a context of strategic downsizing. Journal of Occupational Health Psychology, 2(4), 289303.

Peccei, R. E., van de Voorde, F. C., \& Van Veldhoven, M. J. P. M. (2012). HRM, well-being and performance: A theoretical and empirical review. In J. Paauwe, D. E. Guest, \& P. M. Wright (Eds.), HRM \& performance: Achievements and challenges. Chichester: Wiley.

Ping, R. A. (1995). A parsimonious estimating technique for interaction and quadratic latent variables. Journal of Marketing Research, 32(3), 336-347.

Podsakoff, P. M., MacKenzie, S. B., \& Podsakoff, N. P. (2012). Sources of method bias in social science research and recommendations on how to control it. Annual Review of Psychology, 63, 539-569.

Rafferty, A., \& Jimmieson, N. (2017). Subjective perceptions of organizational change and employee resistance to change: Direct and mediated relationships with employee well-being. British Journal of Management, 28(2), 248-264.

Please cite as: Harney, B., Fu, N., \& Freeney, Y. (2018). Balancing tensions: Buffering the impact of organisational restructuring and downsizing on employee well-being. Human Resource Management Journal, 28(2), 235-254. https://onlinelibrary.wiley.com/doi/10.1111/1748$\underline{8583.12175}$ 
Roche, W. K., \& Teague, P. (2012). Business partners and working the pumps: Human resource managers in the recession. Human Relations, 65(10), 1333-1358.

Roche, W. K., \& Teague, P. (2014). Do recessions transform work and employment? Evidence from Ireland. British Journal of Industrial Relations, 52(2), 261-285.

Russell, H., \& McGinnity, F. (2014). Under pressure: The impact of recession on employees in Ireland. British Journal of Industrial Relations, 52(2), 286-307.

Spreitzer, G., \& Mishra, A. (2002). To stay or to go: Voluntary survivor turnover following an organisational downsizing. Journal of Organisational Behaviour, 23(6), 707-729.

Teague, P., \& Roche, W. K. (2014). Recessionary bundles: HR practices in the Irish economic crisis. Human Resource Management Journal, 24(2), 176-192.

Trevor, C. O., \& Nyberg, A. J. (2008). Keeping your headcount when all about you are losing theirs: Downsizing, voluntary turnover rates, and the moderating role of HR practices. Academy of Management Journal, 51(2), 259-276.

Van de Voorde, K., Van Veldhoven, M., \& Veld, M. (2016). Connecting empowerment-focused HRM and labour productivity to work engagement: The mediating role of job demands and resources. Human Resource Management Journal, 26(2), 192-210.

Van Dierendonck, D., \& Jacobs, G. (2012). Survivors and victims, a meta-analytical review of fairness and organizational commitment after downsizing. British Journal of Management, 23(1), 96-109.

Warr, P. (1987). Work, unemployment, and mental health. Oxford: Oxford University Press.

Wichert, I. (2002). Job insecurity and work intensity: The effects on health and well-being. In B. Burchell, D. Ladipo, \& F. Wilkinson (Eds.), Job insecurity and work intensity (pp. 92-111). London and New York: Routledge.

Wood, S., \& de Menezes, L. M. (2011). High involvement management, high-performance work systems and well-being. International Journal of Human Resource Management, 22(7), 15861610.

Wood, S., Van Veldhoven, M., Croon, M., \& De Menezes, L. M. (2012). Enriched job design, high involvement management and organizational performance: The mediating roles of job satisfaction and well-being. Human Relations, 65(4), 419-445.

Zatzick, C., \& Iverson, R. (2006). High-involvement management and workforce reduction: Competitive advantage or disadvantage? Academy of Management Journal, 49(5), 999-1001.

Please cite as: Harney, B., Fu, N., \& Freeney, Y. (2018). Balancing tensions: Buffering the impact of organisational restructuring and downsizing on employee well-being. Human Resource Management Journal, 28(2), 235-254. https://onlinelibrary.wiley.com/doi/10.1111/1748$\underline{8583.12175}$ 


\section{Table 1}

\begin{tabular}{|c|c|c|c|c|c|c|c|c|c|c|c|c|c|c|c|c|c|}
\hline & & Mean & $S D$ & 1 & 2 & 3 & 4 & 5 & 6 & 7 & 8 & 9 & 10 & 11 & 12 & 13 & 14 \\
\hline 1. & Exhaustion & 2.64 & .91 & (83) & & & & & & & & & & & & & \\
\hline 2. & Job satisfaction & 3.11 & .50 & $-.31^{* *}$ & (.73) & & & & & & & & & & & & \\
\hline 3. & Work intensity & .01 & .71 & $.57^{* *}$ & $-.10^{* *}$ & $(.75)$ & & & & & & & & & & & \\
\hline 4. & Consultation & 3.78 & .99 & $-.23^{* *}$ & $34^{* *}$ & $-.07^{* *}$ & $(.78)$ & & & & & & & & & & \\
\hline 5. & Restructuring & .48 & .50 & $.13^{* *}$ & $-.05^{* *}$ & $.14^{* *}$ & $-.04^{* *}$ & & & & & & & & & & \\
\hline 6. & Downsizing & .57 & .49 & $.12^{* *}$ & $-.10^{* *}$ & $.11^{* *}$ & $-.09^{* *}$ & $.19^{* *}$ & & & & & & & & & \\
\hline 7. & Gender (female) & .52 & .50 & .00 & $.04 *$ & $.06^{* *}$ & $-.03^{*}$ & $-.07^{* *}$ & $-.09^{* *}$ & & & & & & & & \\
\hline 8. & Tenure (years) & 11.65 & 10.05 & .01 & .01 & $.08^{* *}$ & .02 & $.10^{* *}$ & $.09^{* *}$ & $-.10^{* *}$ & & & & & & & \\
\hline 9. & Education & 1.97 & .88 & $.13^{* *}$ & $.05^{* *}$ & $.21^{* *}$ & $.07^{* *}$ & $.07^{* *}$ & $.05^{* *}$ & $.04^{* *}$ & $-.08 * *$ & & & & & & \\
\hline 10. & Union ship & .44 & .50 & $.07^{* *}$ & $-.04^{* *}$ & $.10^{* *}$ & $-.12^{* *}$ & $.11^{* *}$ & $.08^{* *}$ & $.06 * *$ & $.36^{* *}$ & .01 & & & & & \\
\hline 11. & Job grades & .63 & .48 & $-.14^{* *}$ & $-.04^{*}$ & $-.24^{* *}$ & $-.16^{* *}$ & $-.09^{* *}$ & $-.08 * *$ & $.12^{* *}$ & $-.25^{* *}$ & $-.21^{* *}$ & .02 & & & & \\
\hline 12. & Sector & 2.24 & .94 & $-.05^{* *}$ & .02 & $-.15^{* *}$ & $.06^{\circ *}$ & -.03 & .01 & $-.19^{* *}$ & $-.24^{* *}$ & $-.16^{* *}$ & $-.47^{* *}$ & .02 & & & \\
\hline 13. & Firm size & 2.02 & .82 & $.10^{* *}$ & .01 & $.09^{* *}$ & $-.05^{* *}$ & $.23^{* *}$ & $.18^{* *}$ & $-.09^{* *}$ & $.12^{* *}$ & $.11^{* *}$ & $.22^{* *}$ & $-.07^{* *}$ & $-.10^{* *}$ & & \\
\hline 14. & Health status & 4.03 & .91 & $-.12^{* *}$ & $.15^{* *}$ & -.02 & $.09^{* *}$ & -.02 & $-.04^{* *}$ & $.10^{* *}$ & $-.09^{* *}$ & $.11^{* *}$ & $-.03^{*}$ & .00 & .00 & -.01 & \\
\hline 15. & Job security & & & $-.08^{* *}$ & $.13^{* *}$ & .02 & $.11^{* *}$ & $-.11^{* *}$ & $-.18^{* *}$ & $.06 * *$ & .00 & $-.05^{* *}$ & $.06^{* *}$ & -.03 & $.11^{* *}$ & -.01 & $.04^{* *}$ \\
\hline
\end{tabular}

Note. $N=4,492$ (listwise). The numbers in the brackets are the Cronbach's alphas.

${ }^{* *} p<.01$,

${ }^{*} p<.05$ (two-tailed test).

\section{Table 2}

TABLE 2 Effects of other variables on employee outcomes

\begin{tabular}{llll|}
\hline Control variables & Work intensity & Employee exhaustion & Job satisfaction \\
\hline Gender (female) & $.06^{* *}$ & $-.04^{*}$ & $.06^{*}$ \\
\hline Tenure (years) & -.02 & $-.05^{* *}$ & $.04^{*}$ \\
\hline Education dummy 1 & $-.17^{* *}$ & $-.00^{*}$ & -.02 \\
\hline Education dummy 2 & -.04 & .00 & $-.04^{*}$ \\
\hline Unionship & $.04^{* *}$ & .02 & -.02 \\
\hline Job grade dummy 1 & $-.36^{* * *}$ & -.04 & $-.06^{*}$ \\
\hline Job grade dummy 2 & $-.16^{* * *}$ & -.01 & $-.10^{* * *}$ \\
\hline Job grade dummy 3 & $-.09^{* * *}$ & -.03 & -.03 \\
\hline Sector dummy 1 & $.12^{* * *}$ & $-.08^{* * *}$ & -.02 \\
\hline Sector dummy 2 & -.01 & .00 & .02 \\
\hline Firm size dummy 1 & .01 & $-.05^{* *}$ & $-.06^{* *}$ \\
\hline Firm size dummy 2 & .03 & -.02 & -.02 \\
\hline Health status & $-.06^{* *}$ & $-.08^{* * *}$ & $.11^{* * *}$ \\
\hline Job security & -.02 & $-.04^{* *}$ & $.08^{* * *}$ \\
\hline Consultation & - & $-.22^{* * *}$ & $.40^{* * *}$ \\
\hline Indirect effect of work intensity (restructuring) & - & .0629 & -.0064 \\
\hline Indirect effect of work intensity (restructuring) & - & .0542 & -.0054 \\
\hline
\end{tabular}

Note. Standardised coefficients were reported. $N=4,588$ (Listwise). All tests were two-tailed. Education dummy: $1=$ Leaving certificate and below, 2 = PLC diploma; Job grade dummy: 1 = front-line employees, 2 = supervisors, 3 = middle managers. Sector dummy: 1 = Public sector, 2 = Commercial Semi-State sector; Firm size dummy: 1 = Small firms, 2 = Medium size firms. ${ }^{* * *} p<.001$,

$* p<.01$,

${ }^{*} p<.05$.

Please cite as: Harney, B., Fu, N., \& Freeney, Y. (2018). Balancing tensions: Buffering the impact of organisational restructuring and downsizing on employee well-being. Human Resource Management Journal, 28(2), 235-254. https://onlinelibrary.wiley.com/doi/10.1111/1748- 